\title{
Sınıf Öğretmenlerinin Sosyal Bilgiler Dersinde Okuryazarlık Becerilerini Kazandırmaya Yönelik Gerçekleştirdikleri Uygulamalar
}

\section{The Implementations Classroom Teachers Use In Order To Reinforce Literacy Skills in Social Studies Classes}

Tuğba SELANIK AY

Afyon Kocatepe University, Turkey

tsay@aku.edu.tr

\section{Ümit YAVUZ}

Gömü İlkokulu, Turkey

umityavuz1453@gmail.com

\begin{abstract}
$\ddot{\mathbf{O z}} \mathbf{1}^{1}$
Sosyal Bilgiler dersi insanı, toplumu ve bunlarla ilişkisi çerçevesinde çevreyi konu alanı olarak inceleyen bir derstir. Bu bağlamda günlük yaşam içinde bu amacı gerçekleştirmeye dönük olarak farklı türde pek çok okuryazarlık becerisinin kazandırılmasını da içerir. Sosyal Bilgiler dersinde kazandırılabilecek okuryazarlık becerileri çevre, hukuk, ekonomi, teknoloji, tarih, medya, harita, coğrafya, eleştirel ve politik okuryazarlık biçiminde sıralanabilir. Bu araştırmanın temel amacı sınıf öğretmenlerinin Sosyal Bilgiler dersinde okuryazarlık becerileri kazandırmaya yönelik gerçekleştirdikleri uygulamaları belirlemektir. Araştırmanın katılımcılarını 2015-2016 öğretim yılı bahar döneminde Afyon İli merkezinde yer alan 9 devlet ilkokulunda görev yapmakta olan 110 sinıf öğretmeni oluşturmaktadır. Araştırma tarama modelinde, betimsel bir çalışmadır. Araştırmada, sınıf öğretmenlerinin Sosyal Bilgiler dersinde çeşitli okuryazarlık becerilerini kazandırmaya yönelik gerçekleştirdikleri uygulamaları belirlemek amacıyla araştırmacılar tarafindan geliştirilen 10 okuryazarlık becerisini kazandırmaya yönelik olarak gerçekleştirilebilecek 105 uygulamayı içeren kapalı uçlu anket kullanılmıştır. Elde edilen veriler frekans ve yüzdeler biçiminde sunulmuştur. Araştırma sonucunda sınıf öğretmenlerinin okuryazarlık bağlamında Sosyal Bilgiler dersinde yer verdiği uygulamalar incelendiğinde sınıf öğretmenlerinin, bilgi düzeyinde uygulamaları gerçekleştirdiği ancak öğrencinin günlük yaşamı ilişkilendirmesini sağlayacak beceri düzeyinde uygulamalara en az düzeyde yer verdiği sonucuna ulaşııışıtır. Bunun yanı sıra her bir okuryazarlık türü ile ilgili sınıf öğretmenlerinin gerçekleştirdikleri uygulamaların sosyal bilgiler dersi öğretim
\end{abstract}

\footnotetext{
${ }^{1}$ Araştırma makalesi, illk gönderim tarihi: 21.05.2016 Kabul tarihi: 05.08.2016
} 
programında yer alan kazanımlarla uyumlu uygulamalar olduğu sonucuna ulaşılmıştır. Elde edilen sonuçlar 1şı̆̆gnda okuryazarlık becerilerinin kazandırılmasında okul dışı öğrenme ortamlarından yararlanmaya yönelik hizmet öncesi eğitim ile öğretmen adaylarına, hizmet içi eğitim yoluyla da öğretmenlere destek sağlanması; okuryazarlık becerilerinin kazandırılmasına yönelik öğrenciler üzerinde gerçekleştirilen uygulamaları içeren çeşitli deneysel ya da kuramsal araştırmalar yapılması önerilmiştir.

Anahtar Kelimeler: Sosyal Bilgiler öğretimi, okuryazarlık becerileri, sınıf öğretmenleri

\begin{abstract}
Social Studies course mainly deals with people, society and the relationship between people and society. Therefore, one of the basic goals of Social Studies course is to provide students with many distinct literacy skills. Literacy skills covered in Social Studies course include those about environment, law, economics, technology, history, media, maps, geography, critical and political. The aim of this study is to reveal which activities are used by teachers to reinforce these literacy skills. The participants of the study were a total of 110 classroom teachers working at nine different public primary schools in Afyon during the spring semester of the school year of 2015-2016. The study was designed as a descriptive research. The data of the study were collected through a survey questionnaire developed by the authors. The data collection tool included 105 items about ten distinct literacy skills. The data were analysed using frequency and percentage. The findings of the study showed that the participants conducted activities about literacy skills, but they less dealt with those activities which related these activities with daily life practices. In addition, it was found that all activities concerning literacy skills done by the participants were consistent with the goals of Social Studies courses. Based on the findings of the study it can be suggested that in reinforcing literacy skills out of school environment should be used by teachers. This requirement can be emphasized both in teacher training programs and in in-service training courses. On the other hand, the activities about literacy skills should be analysed in future studies.
\end{abstract}

Key terms: Social Studies teaching, literary skills, classroom teachers 
Anadolu Journal of Educational Sciences International, July 2016, 6(2)

\section{Giriş}

Sosyal Bilgiler dersinin ortaya çıkmasından beri bitmeyen bir tartışma, onun ne olduğu veya ne olması gerektiği olmuştur. Bu durum Sosyal Bilgilerin farklı tanımlarını doğurmuştur. Wesley (1937) Sosyal Bilgileri "pedagojik amaçlarla sosyal bilimleri basitleştirerek kaynaştıran bir ders” olarak tanımlarken; ABD’nin Sosyal Bilgiler Ulusal Konseyi (National Council for the Social Studies-NCSS'nin) 1992'de, Sosyal Bilgilerin, “yetkin vatandaş1 desteklemek için sosyal ve insanî bilimleri birleştiren bir alan" olduğu biçimde tanımlamalar gerçekleştirmiştir (İnan, 2014). Sosyal Bilgiler dersi insanı, toplumu ve bunlarla ilişkisi çerçevesinde çevreyi konu alanı olarak incelemektedir. (Kabapınar, 2012: 3). Sosyal Bilgiler, antropoloji, arkeoloji, ekonomi, coğrafya, tarih, hukuk, felsefe, siyaset bilimi, psikoloji, din ve sosyolojinin yanı sıra beşeri bilimler, matematik ve doğa bilimlerden kendine mal ettiği içerik üzerinde sistematik ve eşgüdümlü bir çalışma sağlar (Öztürk, 2006). Tüm bu tanımlama ve açıklamalardan hareketle Sosyal Bilgiler dersinin amaçlarına ulaşılabilmesi için bireylere bu ders aracılığı ile pek çok beceri ve değerin kazandırılması gerektiği açıktır. Bu becerilerin bir kısmı Sosyal Bilgiler dersinin ilişkili olduğu disiplinler ve bu disiplinlerin temel özellikleri de göz önünde bulundurularak çeşitli okuryazarlık becerileri ile ifade edilebilir. Bu okuryazarlık becerileri çevre, hukuk, ekonomi, teknoloji, tarih, medya, harita, coğrafya, eleştirel ve politik okuryazarlıklardır. Kısaca her bir okuryazarlık türü ele alınacak olunursa:

Ekonomi okuryazarlı̆̆g; öğrencilerin yaş düzeylerine uygun olarak üretici, tüketici, çalışan ve yatırımcı olarak rollerinde, sorumluluk sahibi, çalışkan ve dürüst vatandaşlar olarak gelecekte daha iyi kararlar almada, ülkesini ve dünyayı daha iyi anlamada kendilerine yardımcı olacak seviyede ihtiyacı olan ekonomik bilgi, beceri ve tutumlarla donatılmalarıdır (Hayta ve Akhan, 2014: 208). Sosyal Bilgilerin temel amacı etkili vatandaşlar yetiştirmektir. Etkili bir vatandaşın önemli bir özelliği de ekonomi okuryazarı olmasıdır. Bunun için ekonomi eğitimine erken yaşlarda başlamak gerekir (Akhan, 2013: 102). 
Anadolu Journal of Educational Sciences International, July 2016, 6(2)

Çevre okuryazarlı̆̆l; doğal sistemlerin nasıl işlediğini ve bu sistemlerin insanların oluşturduğu sistemler ile nasıl etkileşim içerisinde olduğunun farkında olmaktır. Dolayısıyla Sosyal Bilgilerin bahsedilen genel amacı gerçekleştirildiğinde aslında öğrencilerin çevre okuryazarı birer birey olması sağlanacaktır (Karatekin, 2013: 60). Roth (1992) çevre okuryazarlığını nominal, işlevsel ve eylemsel düzeyde ele almaktadır. Eylemsel çevre okuryazarlığı çevre ile olan etkileşimde etkin rol almayı ve sorunların çözümünde sorumluluk üstlenmeyi içerdiği için öğretmenlerin bu konudaki yeterlik düzeyi ve gerçekleştirdikleri uygulamalar önem taşımaktadır. Artun ve diğerleri (2013)'de bu süreçte öğrencilerde çevre okuryazarlığının oluşmasını ve gelişmesini sağlayacak olan öğretmenlere büyük sorumluluklar düştüğünü belirtmektedir.

Medya okuryazarlığl; beceri, tutum, bilgi ve anlayışlar bütünüdür. Bu bağlamda soru sormay1, seçimler yapmayı, varsayımları sorgulamayı, eleştirmeyi ve medyayı değerlendirmeyi sağlar (Schwarz, 2001:118). Bilgi ve iletişim teknolojilerinin etrafımızı sardığı, özellikle internet sayesinde her türlü bilgi, haber, vb ulaşımın kolaylaştığı, aynı zamanda istemediği halde pek çok mesaja maruz kalan bireylerin hem ihtiyacı olana ulaşması hem de istemediği mesajlardan kendini koruyabilmesi için öğretim süreci içinde medya okuryazarlık becerilerini kazanmış olmaları gerekmektedir. Çünkü günümüz dünyası çok hılı değişen bilgi ve enformasyon ortamına sahiptir. Yanlış ve doğru bilgiler sürekli olarak yığılmalı bir şekilde artmaktadır ve bireylerin doğru bilgiye ulaşabileceği (internet, tv, radyo, dergi, gazete vb.) kitle iletişim araçlarından gereği gibi yararlanmak öncelikle medya okuryazarlığı becerilerini gerektirmektedir (Karaman, 2016:334). İçeriği gereği Sosyal Bilgiler dersi kapsamında dolaylı olarak ele alınmakla birlikte 'Medya Okuryazarlı̆̆g' dersinde doğrudan ele alınmaktadır. Sosyal Bilgiler dersinin canlı bir içeriğe sahip olması nedeniyle bu derste yapılacak etkinliklerle de öğrencilere haberleri anlama, yorumlama ile ilgili bilgi ve becerileri 
Anadolu Journal of Educational Sciences International, July 2016, 6(2)

içeren medya okuryazarlığının kazandırılması büyük önem taşımaktadır (Deveci ve Çengelci, 2008: 30).

Tarih okuryazarlığl; tarih ve okuryazarlık kavramlarının bir araya gelmesinden oluşmaktadır ve en basit haliyle ezberci tarih eğitimine karşı çıkarak tarihsel olaylara ilişsin araştırma sorgulama yapılması, yorum ve değerlendirilmelerde bulunması anlamlarına gelmektedir (Keçe, 2013: 18).

Harita okuryazarlı̆̆l; bireye düşünce, eylem, obje, grafik ve sembolleri anlama ve yorumlama imkânı vererek, yaşam boyu öğrenme bilincini oluşturma, bu bilinci geliştirmede etkin öğrenmelerle problem çözme becerilerini kazanmalarını sağlayabilmektedir. Bilgi çağında bilginin hangi formatlarda üretildiğini ve kullanıldığını anlayabilmek için günümüz insanı çoklu okuryazar olmak zorundadır (Duman ve Girgin, 2007: 185). Coğrafyanın anlaşılabilmesi ve öğrencinin bulunduğu çevreyi tanıması için küçük yaşlardan itibaren çocuklar, harita ve küre kullanmalıdır. Okul çağında bu kazanımı da ancak Sosyal Bilgiler dersi ile harita okuryazarı olarak yetiştirildiği zaman gerçekleştirebilirler (Sönmez, 2013:151). Teknoloji okuryazarliğg; bilgi teknolojilerindeki yenilikleri kavramak, gelişmelere uyum sağlamak, yeni teknolojileri değerlendirmek ve kullanmak becerilerini kapsamaktadır (Aldemir, 2004: 32). Sosyal Bilgiler öğretmenleri toplum ile insan yapımı dünya arasındaki ilişkileri öğretirken, ilköğretim öğrencilerinin teknoloji okuryazarlığı becerilerinin gelişimine önemli katkılarda bulunacaklardır. (Yiğit, 2011: 88).

Coğrafya okuryazarlı̆̆g; Üç farklı seviyede ele alınabilecek coğrafya okuryazarlığı alt düzeyde lokasyon bilme becerisi; orta düzeyde insanın çevre ile olan ilişkisini neden ve sonuçları ile ele almayı bunun yanı sıra sorgulama, doğrulama, değerlendirme ve analiz etme becerilerini; üst düzey ise eleştirel coğrafya okuryazarlığı düzeyinde, milletlerin sahip oldukları güçlerin ve doğal kaynakların farklı olmasının coğrafya ile bağını çözümleyebilme gibi bileşenleri kapsar (Oigara, 2006). 
Politik okuryazarlık; sosyal hayatın nasıl işlediğinin anlaşılabilmesi için günlük yaşamın bir parçası haline gelen politik süreçlere ilişkin eleştirel düşünme becerisine ve temel politik bilgilere sahip olmak biçiminde tanımlanabilir. $\mathrm{Bu}$ nedenle erken yaşlar çocukların demokrasinin işlevleriyle tanıştırılmasının en ideal olduğu yaşlardır. Politik Okuryazar bir birey yetiştirmek ile ilgili önemli sorunlar biri öğrencilere okullarda politikanın süreçleri ve dinamikleri hakkında çok az şey öğretiliyor olmasıdır. Öğrencilere, politikanın doğrudan ya da dolaylı yollardan herkese dokunduğu ve herkesin hayatını etkilediği yeterince gösterilmelidir (Tarhan, 2015).

Hukuk okuryazarlı̆̆g; Sosyal Bilgiler programının hedefleri arasında yer alan; etkin, üretken, hak ve sorumluluklarını bilen ve kullanan vatandaşlar yetiştirebilmek (MEB, 2004) için öğrencilerin hukuk okuryazarı olması önem kazanmaktadır. Oğuz (2013b)'de hukuk okuryazarlığını öğrencileri hukuk alanında birer uzman haline getirmek değil, daha ziyade onların bir vatandaş olarak hukuk kapsamındaki görev ve sorumluluklarının farkına varmalarını sağlamak olarak tanımlamıştır.

Eleştirel okuryazarlık; bireyin okuduklarını yargılaması, sorgulaması, aklını kullanarak bir sonuca varma becerisine sahip olmasıdır. Çağımız toplumunda çevresiyle etkin bir şekilde iletişim kurabilen, çevresinde olup bitenlere eleştirel bir gözle bakabilen bireyler yetiştirmenin önemi daha da artmıştır. Kitap, dergi, gazete, TV, internet vb. yazılı ve görsel iletişim araçları bir yandan insanların yaşamlarını kolaylaştırırken diğer yandan insanları gereksiz, yanlış, eksik bilgiyle karşı karşıya kalmalarına yol açabilmektedir. $\mathrm{Bu}$ nedenle insanların dışarıdan aldıkları bilgiyi olduğu gibi kabul etmek yerine sorgulaması, eleştirmesi, bilginin doğruluğunu araştırması gerekmektedir. Eleştirel okumanın Sosyal Bilgiler dersiyle birlikte ele alınması eleştirel düşünme becerisinin kazanılması açısından önemli olduğu söylenebilir (Özensoy, 2011: 13). 
Öğretmenlerin çeşitli okuryazarlık becerilerine sahip olmaları ve bu becerileri öğrencilere kazandırırken gerçekleştirdikleri uygulamalar etkili bir Sosyal Bilgiler eğitimi için son derece önemlidir. İlgili alanyazın incelendiğinde çevre, hukuk, ekonomi, teknoloji, politika, tarih, medya, harita, coğrafya ve eleştirel okuryazarlıklar bağlamında yapılan bağımsız araştırmalara (Sünbüloğlu ve Sünbüloğlu, 2000; Schwarz, 2001; Kaminski, Seel ve Cullen, 2003; Aldemir, 2004; Lee, 2005; Duman ve Girgin, 2007; Deveci ve Çengelci, 2008; Guofeng ve Gut, 2008; Livingstone, 2008; Stein ve Prewett, 2009; Kurt, 2010; McBeth ve Volk, 2010; Akhan, 2010; Yiğit, 2011; Cooper, 2011; Shibab, 2011; Karatekin, 2012; Karatekin ve Aksoy, 2012; Karatekin, 2013; Keçe, 2013; Oğuz, 2013a; Oğuz, 2013b; Akhan, 2013; Sönmez, 2013; Altun Uzunöz ve Akbaş, 2013; Hayta ve Akhan, 2014; Clark, 2014; Luckhardt, 2014; Tarhan, 2015; Tuna, 2015; Dikmenli, 2015; Karaman, 2016; Avsec ve Jamsek, 2016; Barut, Demirer, Erbaş, Dikmen ve Sak, 2016; Cheung ve Xu, 2016; Lewin, 2016) rastlanmıştır. Ancak Sosyal Bilgiler dersinde bu okuryazarlık becerilerinin her birinin ne şekilde ve ne tür uygulamalar ile kazandırıldığını; hangi okuryazarlık türüne daha ağırlıklı olarak yer verildiğini belirlemeye yönelik herhangi bir araştırmaya rastlanmamıştır. $\mathrm{Bu}$ araştırmanın temel amacı sınıf öğretmenlerinin Sosyal Bilgiler dersinde çeşitli okuryazarlık becerilerini kazandırmaya yönelik olarak gerçekleştirdikleri uygulamaları belirlemek, elde edilen veriler 1şı̆̆ında daha etkili bir Sosyal Bilgiler öğretimi gerçekleştirebilmektir. Bu araştırmanın temel amacı sınıf öğretmenlerinin sosyal bilgiler dersinde okuryazarlık becerilerini kazandırmaya yönelik gerçekleştirdikleri uygulamaların belirlenmesidir. Bu temel amaca bağlı olarak sınıf öğretmenlerinin çevre, hukuk, ekonomi, teknoloji, tarih, medya, harita, coğrafya, eleştirel ve politik okuryazarlık becerilerini kazandırmaya yönelik olarak ne tür uygulamalar gerçekleştirdikleri belirlenmeye çalışılmıştır. 


\section{Yöntem}

$\mathrm{Bu}$ bölümde; araştırmanın modeline, evren ve örnekleme, veri toplama aracı, verilerin toplanmasına ve çözümlenmesine ilişkin bilgilere yer verilmiştir.

\section{Araştırmanın Modeli}

Araştırmada var olan bir durum olduğu gibi betimlenmeye çalışılmış ve araştırma konusu olan bireyler kendi koşulları içerisinde tanımlanmaya çalışılmıştır. Bu yüzden araştırma tarama modelinde, betimsel bir çalışmadır. Araştırmada, sınıf öğretmenlerinin Sosyal Bilgiler dersinde çeşitli okuryazarlık becerilerini kazandırmaya yönelik gerçekleştirdikleri uygulamaları belirlemek amacıyla kapalı uçlu anket kullanılmıştır.

\section{Katılımcılar}

Araştırmanın katılımcılarını 2015-2016 eğitim-öğretim yılı bahar döneminde Afyon İl merkezinde alt (3), orta (3) ve üst (3) sosyo-ekonomik düzeyde yer alan toplam 9 devlet ilkokulunda görev yapan 110 sınıf öğretmeni oluşturmaktadır. Katılımcıların özellikleri Tablo 1'de görülmektedir:

Tablo 1

\section{Katılımcıların özellikleri}

\begin{tabular}{|c|c|c|c|}
\hline & & n & $\%$ \\
\hline \multirow{3}{*}{ Cinsiyetiniz } & Kadın & 67 & 58,2 \\
\hline & Erkek & 43 & 41,8 \\
\hline & Toplam & 110 & 100,0 \\
\hline \multirow{4}{*}{ Öğrenim düzeyiniz } & Lisans tamamlama & 10 & 10,9 \\
\hline & Lisans & 87 & 84,5 \\
\hline & Lisansüstü & 13 & 5,0 \\
\hline & Toplam & 202 & 100,0 \\
\hline \multirow{5}{*}{ Yaşınız } & $22-30$ & 38 & 23,6 \\
\hline & $31-40$ & 22 & 34,5 \\
\hline & $41-50$ & 40 & 31,8 \\
\hline & $51+$ & 10 & 10 \\
\hline & Toplam & 110 & 100,0 \\
\hline \multirow{6}{*}{ Mesleki kıdeminiz } & $1-5$ y1l & 23 & 20,90 \\
\hline & $6-10$ y1l & 17 & 15,45 \\
\hline & $11-15 \mathrm{y} 1 \mathrm{l}$ & 19 & 17,27 \\
\hline & $16-20 \mathrm{y} 11$ & 23 & 20,90 \\
\hline & $21+$ & 28 & 25,45 \\
\hline & Toplam & 110 & 100,0 \\
\hline
\end{tabular}




\section{Veri Toplama Aracı}

Araştırmada veri toplama aracı olarak kapalı uçlu anket formu kullanılmıştır. Kapalı uçlu soru, cevaplayıcıya olası cevap seçeneklerinin verildiği soru türüdür. Yapılandırılmış sorular ismiyle bilinen bu tür sorularda cevaplayıcı, soruları güvenilir ve hızlı bir şekilde analiz eder (Büyüköztürk, 2011). Bireylerin bazı davranışları ve bazı düşünsel, duygusal, inançsal, güdüsel, algısal özelliklerini doğrudan gözlemek olanaklı olmadığından, bu tür durumları incelemek için araştırmalarda anket yöntemi kullanılır (Ekiz, 2003; Karasar, 2015; Sümbüloğlu, 2000, Şimşek ve Yıldırım, 2005). Veri toplama aracı geliştirme sürecinde önce 20 sınıf öğretmenine okuryazarlık becerilerini geliştirmek için sınıflarında ne tür uygulamalar gerçekleştirdikleri açık uçlu soru biçiminde sorulmuş alınan cevaplardan ve literatürden hareketle taslak anket formu oluşturulmuştur. Taslak anket formu ilgili alan uzmanlarına da inceletilmiş ve gerekli düzeltmeler yapılmıştır. Hazırlanan anket formu daha sonra pilot uygulama için Afyon ili Emirdağ ilçesi merkezinde görev yapmakta olan 110 sınıf öğretmenine uygulanmıştır. Bu süreç sonucunda veri toplama aracı 10 farklı okuryazarlık türünü kapsayan 103 maddeden oluşan bir kapalı uçlu anket haline gelmiş ve bu biçimi ile uygulanmıştır. Ankette yer alan okuryazarlık türleri: ekonomi okuryazarlığı, çevre okuryazarlığı, medya okuryazarlığı, tarih okuryazarlığı, harita okuryazarlığı, teknoloji okuryazarlığı, coğrafya okuryazarlığı, politik okuryazarlık, hukuk okuryazarlığı ve eleştirel okuryazarlıktır. Anket formundaki maddeler (1) Katılıyorum, (2) Katılmıorum biçimindedir. Elde edilen verilerin analizi sonucunda bazı maddeler çıkarılmış ve anketin güvenirlik katsayısı (Cronbach Alpha) 0,91 olarak bulunmuştur.

\section{Bulgular ve Yorum}

$\mathrm{Bu}$ bölümde araştırmada elde edilen bulgular tablolarla frekans ve yüzdeler biçiminde sunulmuştur. Veri toplama aracında yer alan on farklı okuryazarlık becerisi ile ilgili olarak elde edilen veriler ayrı ayrı tablolar halinde sunulmuştur. Sınıf öğretmenlerinin, Sosyal 
Bilgiler dersinde ekonomi okuryazarlığı becerisi kazandırmaya yönelik gerçekleştirdikleri uygulamalar Tablo 2'de verilmiştir.

Tablo 2

Sını öğretmenlerinin ekonomi okuryazarlı̆̆ı bağlamında gerçekleştirdiği uygulamalar

\begin{tabular}{|c|c|c|}
\hline Maddeler & $\mathbf{F}$ & $\%$ \\
\hline Tutumluluk üzerinde durma & 107 & $\% 97,3$ \\
\hline Öğrencilerin doğal kaynakların etkili kullanımı konusunda bilgi edinmelerini sağlama & 106 & $\% 96,4$ \\
\hline $\begin{array}{l}\text { Öğrencileri bir ürün alırken son kullanma tarihine dikkat etmeleri gerektiği konusunda } \\
\text { bilgilendirme }\end{array}$ & 104 & $\% 94,5$ \\
\hline $\begin{array}{l}\text { Öğrencileri bir ürün alırken TSE damgasına dikkat etmeleri gerektiği konusunda } \\
\text { bilgilendirme }\end{array}$ & 104 & $\% 94,5$ \\
\hline Öğrencilerin istek ve ihtiyaçlarını ayırt etmesini sağlama & 98 & $\% 89,1$ \\
\hline $\begin{array}{l}\text { Çeşitli meslekler ve toplumda üstlendikleri role ilişkin öğrencilerin bilgi edinmelerini } \\
\text { sağlama }\end{array}$ & 79 & $\% 71,8$ \\
\hline $\begin{array}{l}\text { Market gibi mekânlarda alışverişte dikkat edilmesi gereken unsurlara yönelik uygulamalar } \\
\text { gerçekleştirme }\end{array}$ & 62 & $\% 56,4$ \\
\hline Öğrencilerin aile katılımlı bütçe hazırlama uygulamaları yapmalarını isteme & 47 & $\% 42,7$ \\
\hline $\begin{array}{l}\text { Öğrencilerin doğal kaynakların etkili kullanımına ilişkin gözlem ya da uygulamaya dayalı } \\
\text { çeşitli projeler geliştirmelerini isteme }\end{array}$ & 45 & $\% 40,9$ \\
\hline Öğrencileri patent, telif hakkı gibi konularda bilgilendirme & 32 & $\% 29,1$ \\
\hline Farklı meslek gruplarından insanları kaynak kişi olarak sınıfa davet etme & 15 & $\% 13,6$ \\
\hline Öğrencileri üretim ile ilgili çeşitli kurum kuruluş ve fabrikalara götürme & 7 & $\% 6,4$ \\
\hline
\end{tabular}

Tablo 2'de de görüldüğü gibi sınıf öğretmenlerinin ekonomi okuryazarlığı becerisi kazandırmaya yönelik olarak gerçekleştirdikleri uygulamalar incelendiğinde en fazla tutumluluk üzerinde durma $(\% 97,3)$; öğrencilerin doğal kaynakların etkili kullanımı konusunda bilgi edinmelerini sağlama $(\% 96,4)$; ürünlerin son kullanma tarihine dikkat etmeleri konusunda bilgi edinmelerini sağlama $(\% 94,5)$; bir ürün alırken TSE damgasına dikkat etmelerini sağlama $(\% 94,5)$ ve öğrencilerin istek ve ihtiyaçlarını ayırt etmesini sağlamanın belirtildiği $(\% 89,1)$ görülmektedir. Buna karşın kurum, kuruluş ve fabrikalara götürme $(\% 6,4)$; kaynak kişi davet etme $(\% 13,6)$; gibi sınıf dışında gerçekleştirilen uygulamaların sınıf öğretmenleri tarafından en az gerçekleştirilen uygulamalar olduğu görülmektedir. Ekonomi okuryazarlığı ile ilgili bulgular incelendiğinde; sınıf öğretmenlerinin bilgiye dayalı uygulamalara öncelik verdiği, sınıf dışı uygulamaları en az düzeyde gerçekleştirdiği söylenebilir. Oysa ki Hood, Stein ve McCain (2009) ekonomi okuryazarlığının ekonomi, üretim ve tüketim ile ilgili bilginin yanı sıra günlük yaşamda 
kişinin içinde bulunduğu ekonomi ile ilgili kurum ve ofislerle (Banka, döviz büroları, emlak büroları...vb) de iletişim kurmayı kapsadığını belirtmişlerdir. Sınıf öğretmenlerinin çevre okuryazarlığg bağlamında gerçekleştirdiği uygulamalar Tablo 3’te görülmektedir:

Tablo 3

Sınıf öğretmenlerinin çevre okuryazarlı̆̆ı bă̆lamında gerçekleştirdiği uygulamalar

\begin{tabular}{llc}
\hline Maddeler & F & \% \\
\hline Öğrencilerden yakın çevrelerindeki çevre sorunlarını belirlemelerini isteme & 99 & $\% 90$ \\
Öğrencilerin çevrecilik ile ilgili bilgi edinmelerini sağlama & 98 & $\% 89,1$ \\
Öğrencilerin atık malzemelerin geri dönüşümü ile ilgili uygulamalar yapma & 82 & $\% 74,5$ \\
Öğrencilerin çevre sorunlarının çözümüne yönelik uygulamalar yapmalarını isteme & 78 & $\% 70,9$ \\
Doğal ve yapay çevreyi birlikte ele alma & 77 & $\% 70$ \\
Öğrencilerimle birlikte fidan dikme gibi uygulamalar düzenleme & 76 & $\% 69,1$ \\
Öğrencilerin çevre ile ilgili belgesel, gazete, dergi gibi bilgilendirici çalışmaları takip etmeleri & 60 & $\% 54,5$ \\
konusunda teşvik etme & 60 & $\% 54,5$ \\
Çevre ile ilgili öğrenci kulüplerine öğrencileri yönlendirme & 28 & $\% 25,5$ \\
Öğrencilerimle birlikte sokak hayvanlarına yardım etme gibi uygulamalar gerçekleştirme & 20 & $\% 18,2$ \\
Öğrencilerimin çevreci sivil toplum kuruluşları ile gerçekleştirebileceği etkinlikler düzenleme & 19 & $\% 17,3$ \\
Sınıfa çevreci sivil toplum kuruluşlarından uzman kişileri sınıfa davet etme & 8 & $\% 7,3$ \\
Hayvan barınaklarına geziler düzenleme & & \\
\hline
\end{tabular}

Tablo 3'te de görüldüğü gibi sınıf öğretmenlerinin çevre okuryazarlığı becerisi kazandırmaya yönelik olarak gerçekleştirdikleri uygulamalar incelendiğinde en fazla öğrencilerin yakın çevrelerindeki çevre sorunlarını belirlemelerini sağlama (\%90); öğrencilerin çevrecilik ile ilgili bilgi edinmelerini sağlama $(\% 89,1)$; atık maddeler ile ilgili uygulamalar yaptırma $(\% 74,5)$; olduğu görüldü. Buna karşın öğrencilerle hayvan barınaklarına geziler düzenleme $(\% 7,3)$; sınıfa çevreci sivil toplum kuruluşlarından uzman kişileri davet etme $(\% 17,3)$; çevreci sivil toplum kuruluşları ile etkinlikler düzenleme $(\%$ 18,2) gibi uygulamaların en az gerçekleştirilen uygulamalar olduğu görülmektedir. Çevre okuryazarlığı ile ilgili bulgular incelendiğinde sınıf öğretmenlerinin Sosyal Bilgiler kitabında yer alan bilgiye dayalı uygulamaları gerçekleştirdiği ancak fidan dikme ve geri dönüşüm dışında konuları gerçek hayatla ilişkilendirme konusunda, sınıf dışı uygulamaların en az düzeyde yapıldığı söylenebilir. sınıf öğretmenlerinin belirttiği uygulamaların bilgi, duyarlılık, davranış boyutlarında olduğu görülmektedir. McBeth ve Volk (2010) da çevre okuryazarı düzeyine 
ulaşmanın bilgi, duyarlılık ve davranış boyutlarında farkındalık sahibi olmakla mümkün olduğunu ifade etmişlerdir. Sınıf öğretmenlerinin, Sosyal Bilgiler dersinde öğrencilerine Medya Okuryazarlığı becerisi kazandırmaya yönelik gerçekleştirdikleri uygulamalar Tablo 4'te görülmektedir.

Tablo 4

Sınıf öğretmenlerinin medya okuryazarlı̆̆ bă̆lamında gerçekleştirdiği uygulamalar

\begin{tabular}{lll}
\hline Maddeler & f & \% \\
\hline Öğrencilerin farklı kaynaklardan araştırmalar yapmalarını isteme & 92 & $\% 83,6$ \\
Öğrencilerin hava durumunu düzenli olarak takip etmelerini teşvik etme & 80 & $\% 72,7$ \\
Öğrencilerin akıllı işaretler ile ilgili bilgi edinmelerini sağlama & 65 & $\% 59,1$ \\
Öğrencilerin sınıfa düzenli olarak gazete haberleri getirmelerini isteme & 42 & $\% 38,2$ \\
İkilem içeren örnek olaylar ile sınıf tartışmaları düzenleme & 36 & $\% 32,7$ \\
Öğrencilerin hava durumunu düzenli olarak takip ederek rapor tutmalarını isteme & $34 \% 30,9$ \\
Derslerde ilgili konularda reklamlardan yararlanma ve sınıf tartışmaları düzenleme & 32 & $\% 29,1$ \\
Sınıfa getirilen gazete haberleri ya da haber bülteni görüntüleri ile ilgili sınıf tartışmaları & 29 & $\% 26,4$ \\
düzenleme & & \\
Öğrencilerin faklı kaynaklardan hazırlanmalarını gerektiren münazaralar düzenleme & $17 \% 15,5$ \\
Sınıfta bülten tahtası kullanma & $13 \% 12,7$ \\
Sinıfa konularla ilgili karikatürler getirme sınıf tartışmaları düzenleme & $13 \% 11,8$ \\
Öğrencilerin medya analiz çalışmaları yapmalarını isteme & $8 \% 7,3$ \\
\hline
\end{tabular}

Tablo 4'te de görüldüğü gibi sınıf öğretmenlerinin medya okuryazarlığg becerisini kazandırmaya yönelik olarak gerçekleştirdiği uygulamalar incelendiğinde en fazla öğrencilerin farklı kaynaklardan araştırmalar yapmalarını sağlama $(\% 83,6)$; hava durumunu düzenli olarak takip etmelerini sağlama(\%72,7); akıllı işaretlerle ilgili bilgi edinmelerini sağlama $(59,1)$ olduğu görüldü. Buna karşın öğrencilerin medya analiz çalışmaları yapmalarını isteme $(\% 7,3)$; sınıfa karikatürler getirerek sınıf tartışmaları düzenleme $(\% 11,8)$; sınıfta bülten tahtası kullanma $(\% 12,7)$ ve farklı kaynaklardan hazırlanmalarını gerektiren münazaralar düzenleme $(\% 15,5)$ gibi uygulamaların en az gerçekleştirilen uygulamalar olduğu görülmektedir. Wan ve Gut (2008) medya ürünlerinin değer, inanç, davranış, ekonomik faktörler gibi pek çok boyutu içerdiğini dolayısıyla öğrencilerin bu boyutları fark etmelerine yönelik uygulamaların medya okuryazarı birey yetiştirme sürecinde etkili olduğunu belirtmiştir. Livingstone (2008) da medya ürünlerinin tartışılması ile dinleyici 
aşamasından medya okuryazarı birey olmaya geçişin olanaklı olabileceğini ifade etmiştir. Medya okuryazarlığı ile ilgili bulgular incelendiğinde sınıf öğretmenlerinin öğrencileri araştırmaya yönlendirdiği buna karşın öğrencilerin medya ile ilgili olumlu olumsuz düşüncelerini söyleyebileceği sınıf tartışmaları ve medya ile ilgili sınıf dışı uygulamalara az yer verdiği söylenebilir. Stein ve Prewett (2009) medya okuryazarlığının amaçları ve medya okuryazarlık düzeylerine ilişkin alanyazında çok sayıda araştırma gerçekleştirilmesine karşın medya okuryazarlığı bağlamında gerçekleştirilen uygulamaları içeren araştırmalara pek rastlanılmadığını belirtmişlerdir. Bu bağlamda Tablo 4'te belirtilen sınıf öğretmenlerinin sosyal bilgiler dersinde gerçekleştirdikleri medya okuryazarlığı uygulamalarının alana katkı sağlayacağı söylenebilir. Sınıf öğretmenlerinin, Sosyal Bilgiler dersinde öğrencilerine Tarih Okuryazarlığı becerisi kazandırmaya yönelik gerçekleştirdikleri uygulamalar Tablo 5'te sunulmuştur.

\section{Tablo 5}

\section{Sınıf ögretmenlerinin tarih okuryazarlı̆̆ı bă̆lamında gerçekleştirdiği uygulamalar}

\begin{tabular}{lll}
\hline Maddeler & f & $\%$ \\
\hline Ulusal değerler üzerinde durma & 105 & $\% 95,5$ \\
Evrensel değerler üzerinde durma & 83 & $\% 75,5$ \\
Olayları kronolojik sıraya koyma ile ilgili uygulamalar yaptırma & 82 & $\% 74,5$ \\
Tarihi belgeler ve fotoğraflar gösterme & 80 & $\% 72,7$ \\
Yaşadıkları yere ilişkin mani, türkü, tekerleme, efsane, halk hikâyeleri gibi türleri araştırıp & 72 & $\% 65,5$ \\
sınıfta paylaşmalarına yönelik uygulamalar gerçekleştirme & & \\
Sözlü tarih çalışmaları yaptırma & 58 & $\% 52,7$ \\
Öğrencilerime tarihi belgeseller izletme & 56 & $\% 50,9$ \\
Öğrencilerin tarihsel empati kurmalarına yönelik çeşitli uygulamalar yapmalarını isteme & 49 & $\% 44,5$ \\
Öğrencilerin geçmişte yaşanan olaylardan ve gelişmelerden hareketle geleceğe ilişkin planlar & 48 & $\% 43,6$ \\
yapmalarını teşvik etme & & \\
Farklı dönemlere ait sanat eserleri gösterme & 38 & $\% 34,5$ \\
Tarihi metinler ile ilgili örnekler sunma & 37 & $\% 33,6$ \\
Tarihi binalar gösterme & 34 & $\% 30,9$ \\
Öğrencilerin geçmişten kalma eşyalar toplamaları ve sergilemelerini sağlama & 23 & $\% 20,9$ \\
Sanal müze ve sanal alan gezileri düzenleme & 19 & $\% 17,3$ \\
Müze ve tarihi yerlere geziler düzenleme & 8 & $\% 7,3$ \\
\hline
\end{tabular}

Tablo 5'te de görüldüğü gibi sınıf öğretmenlerinin Tarih Okuryazarlığı becerisini kazandırmaya yönelik olarak gerçekleştirdiği uygulamalar incelendiğinde en fazla ulusal değerler üzerinde durma $(\% 95,5)$; evrensel değerler üzerinde durma $(\% 75,5)$; olayları 
kronolojik sıraya koyma gibi uygulamaları yapma $(\% 74,5)$ ve öğrencilere tarihi belgeler ve fotoğraflar gösterme $(\% 72,7)$ olduğu görülmektedir. Buna karşın müze ve tarihi yerlere geziler düzenleme $(\% 7,3)$; sanal müze ve sanal alan gezileri düzenleme $(\% 17,3)$ ve öğrencilerin geçmişten kalma eşyalarını toplamalarına ve sergilemelerine olanak sağlayacak tarih sergileri düzenleme $(\% 20,9)$ gibi uygulamaların en az gerçekleştirilen uygulamalar olduğu görülmektedir. Tarih okuryazarlığı bağlamında sınıf öğretmenlerinin evrensel ve ulusal değerler üzerinde yoğunlaştığı; öğrencilerde tarihsel algının oluşmasına destek olacak müzelere ve tarihi yerlere sınıf dışı geziler düzenleme gibi uygulamalar yeterince yer vermediği söylenebilir. Sınıf öğretmenlerinin, Sosyal Bilgiler dersinde öğrencilerine Harita Okuryazarlığı becerisi kazandırmaya yönelik gerçekleştirdikleri uygulamalar Tablo 6'da sunulmuştur.

Tablo 6

Sınıf öğretmenlerinin harita okuryazarlı̆̆ bă̆lamında gerçekleştirdiği uygulamalar

\begin{tabular}{lll}
\hline Maddeler & f & $\%$ \\
\hline Yön bulma yöntemleri hakkında bilgi edinmelerini sağlama & 107 & $\% 97,3$ \\
Yön bulmaya yönelik uygulamalı etkinlikler yaptırma & 103 & $\% 93,6$ \\
Krokiler çizmelerini isteme & 96 & $\% 87,3$ \\
Dünya üzerinde çeşitli ülkeler olduğunu harita üzerinde gösterme & 92 & $\% 83,6$ \\
Türkiye ve dünya haritası üzerinde çeşitli uygulamalar yaptırma & 88 & $\% 80$ \\
Haritada belli başlı şehir ve ülkelerin yerlerini bulma ile ilgili bilgisayar oyunları oynatma & 48 & $\% 43,6$ \\
"Google Haritalar” gibi uygulamalardan yararlanma & 47 & $\% 42,7$ \\
Oryantiring uygulamaları yaptırma & 9 & $\% 8,2$ \\
\hline
\end{tabular}

Tablo 6'da da görüldügü gibi sınıf öğretmenin harita okuryazarlığı becerisini kazandırmaya yönelik olarak gerçekleştirdiği uygulamalar incelendiğinde en fazla öğrencilerin yön bulma yöntemleri hakkında bilgi edinmelerini sağlama $(\% 97,3)$; yön bulmaya yönelik uygulamalı etkinlikler yapma $(\% 93,6)$; öğrencilerden kroki çizmelerini isteme $(\% 87,3)$; dünya üzerinde çeşitli ülkeler olduğunu harita üzerinde gösterme $(\% 83,6)$ ve öğrencilerle Türkiye ve dünya haritası üzerinde çeşitli uygulamalar yapma (\%80) olduğu görülmektedir. Buna karşın oryantiring uygulamaları yapma $(\% 8,2)$; Sosyal Bilgiler dersinde öğrencilerle birlikte yön 
bulmada kullanılabilecek "Google Haritalar” gibi uygulamalardan yararlanma $(\% 42,7)$ gibi uygulamaların en az gerçekleştirilen uygulamalar olduğu görülmektedir. Harita okuryazarlığ ile ilgili Sosyal Bilgiler kitaplarında yer alan kazanımlar incelendiğinde öğretmenlerin bu kazanımları bilgi düzeyinde uyguladıkları söylenebilir ancak öğrencilerde kalıcılığı sağlayabilmek için sınıf içi ve sınıf dışı uygulamalara en az düzeyde yer verdiği söylenebilir. Sınıf öğretmenlerinin, Sosyal Bilgiler dersinde öğrencilerine Teknoloji Okuryazarlığı becerisi kazandırmaya yönelik gerçekleştirdikleri uygulamalar Tablo 7’de verilmiştir.

Tablo 7

Sınıf öğretmenlerinin teknoloji okuryazarlı̆̆ bă̆lamında gerçekleştirdiği uygulamalar

\begin{tabular}{|c|c|c|}
\hline Maddeler & $\mathbf{f}$ & $\%$ \\
\hline Derslerde teknolojik aletlerden yararlanma & 103 & $\% 93,6$ \\
\hline Teknolojik aletlerin kullanımı konusunda bilgilendirme & 97 & $\% 88,2$ \\
\hline Teknolojik aletleri kullanırken güvenlik önlemleri alınması konusunda bilgilendirme & 87 & $\% 79,1$ \\
\hline $\begin{array}{l}\text { Geçmişten günümüze teknolojik araçların gelişimini kavramaya yönelik bilgi edinmelerini } \\
\text { sağlama }\end{array}$ & 86 & $\% 78,2$ \\
\hline $\begin{array}{l}\text { İnternetten farklı konularla ilgili görseller (fotoğraf, karikatür, logo..vb) bulmalarına yönelik } \\
\text { uygulamalar yaptırma }\end{array}$ & 52 & $\% 47,3$ \\
\hline Farklı konular ile ilgili bilgisayar oyunları oynatma & 46 & $\% 41,8$ \\
\hline $\begin{array}{l}\text { Çeşitli kurum, kuruluş ve sivil toplum örgütlerinin web sitelerinden yararlanmaya yönelik } \\
\text { uygulamalar yaptırma }\end{array}$ & 38 & $\% 34,5$ \\
\hline E-kitap ve e-kütüphanelerden yararlanmaya yönelik uygulamalar yaptırma & 28 & $\% 25,5$ \\
\hline $\begin{array}{l}\text { Farklı kişilerle görüşmelerine ve ses kaydına alıp sınıfta sunmalarına yönelik uygulamalar } \\
\text { yaptırma }\end{array}$ & 25 & $\% 22,7$ \\
\hline $\begin{array}{l}\text { Farklı konular ile ilgili kamera ve fotoğraf çekimleri yapmalarına yönelik uygulamalar } \\
\text { gerçekleştirme }\end{array}$ & 18 & $\% 16,4$ \\
\hline Power point, prezi gibi uygulamalarla sunum yapmalarını isteme & 16 & $\% 14,5$ \\
\hline Farklı konular ile ilgili uzman kişilere e-posta aracılığı ile ulaşıp bilgi almalarını isteme & 7 & $\% 6,4$ \\
\hline
\end{tabular}

Tablo 7'de de görüldüğü gibi sınıf öğretmenlerinin Teknoloji Okuryazarlığı becerisini kazandırmaya yönelik olarak gerçekleştirdiği uygulamalar incelendiğinde en fazla derslerde teknolojik aletlerden yararlanma $(\% 93,6)$; öğrencileri çevresindeki teknolojik aletlerin kullanımı konusunda bilgilendirme $(\% 88,2)$; öğrencilerin teknolojik aletleri kullanırken güvenlik önlemleri almalarını sağlama $(\% 79,1)$; öğrencilerin geçmişten günümüze teknolojik araçların gelişimini kavramaya yönelik bilgi edinmelerini sağlama (\%78.2) gibi uygulamaların gerçekleştirildiği görülmektedir. Buna karşın öğrencilerin konu ile ilgili uzman 
kişilere e-posta aracılığı ulaşıp bilgi almalarına yönelik uygulamalar yapmalarını sağlama $(\% 6,4)$; öğrencilerin power point gibi uygulamalarla sunum yapmalarını sağlama $(\% 14,5)$ ve öğrencilerin konu ile ilgili çekimler yapmalarına yönelik uygulamalar yapmalarını sağlama $(\% 16,4)$ gibi uygulamaların en az gerçekleştirilen uygulamalar olduğu görülmektedir. Oysa ki Kaminski ve diğ. (2003) araştırmaları sonucunda öğrencilerin \%98'inin e-posta adresi olduğunu; \%81'inin e-postaya dosya ekleme gibi özellikleri bildiğini; zaten çoğu bilgisayar programını kullanabilmek için e-posta adresi kullanma zorunluluğunun olmasının bu sonucun ortaya çıkmasında etkili olduğunu belirtmişlerdir. Bu bağlamda e-posta ile uzman kişilerle iletişime geçme gibi uygulamaların öğrencilerle kolaylıkla yapılabileceği söylenebilir. Teknoloji okuryazarlığıyla ilgili sınıf öğretmenlerinin bilgilendirme düzeyinde uygulamalar yaptığı buna karşın teknolojik aletlerin kullanımı ve sınıf dışı geziler konusunda düşük düzeyde uygulamalar yapıldığı söylenebilir. Sınıf öğretmenlerinin, Sosyal Bilgiler dersinde öğrencilerine Coğrafya Okuryazarlığı becerisi kazandırmaya yönelik gerçekleştirdikleri uygulamalar Tablo 8'de verilmiştir.

Tablo 8

Sınıf öğretmenlerinin coğrafya okuryazarlı̆̆ bağlamında gerçekleştirdiği uygulamalar

\begin{tabular}{lll}
\hline Maddeler & f & \% \\
\hline Mevsime uygun giyinme konusunda bilgi edinmeleri sağlama & 108 & $\% 98,2$ \\
Mevsime uygun yiyecek seçimi konusunda bilgi edinmelerini sağlama & 106 & $\% 96,4$ \\
Yerli malı ürünlerin tüketimine öncelik verme konusunda öğrencileri bilinçlendirmeye & 103 & $\% 93,6$ \\
& & \\
çalı̧ma & 94 & $\% 85,5$ \\
Doğal afetler ve doğal afetlerden korunma yollarına ilişkin bilgi edinmelerini sağlama & 89 & $\% 80,9$ \\
Sosyal Bilgiler dersinde farklı ülkelere ilişkin bilgiler edinmelerini sağlama & 87 & $\% 79,1$ \\
Yaşadıkları bölgede yetişen tarım ürünleri konusunda bilgi edinmelerini sağlama & 82 & $\% 74,5$ \\
Yaşadıkları yerin iklimi konusunda bilgi edinmelerini sağlama & 81 & $\% 73,6$ \\
Yaşadıkları yerin coğrafi özelliklerine ilişkin bilgi edinmelerini sağlama & 79 & $\% 71,8$ \\
Doğal afetlerden korunmaya yönelik tatbikatlar düzenleme & 40 & $\% 36,4$ \\
Doğal ve beşeri unsurları sınıflandırma amaçlı geziler düzenleme & $\% 19,1$ \\
Doğal afetlerden korunmaya yönelik ilgili STK yetkililerini kaynak kişi olarak davet etme & 21 & \\
& & \\
\hline
\end{tabular}

Tablo 8'de de görüldüğü gibi sınıf öğretmenlerinin Coğrafya Okuryazarlığı becerisini kazandırmaya yönelik olarak gerçekleştirdiği uygulamalar incelendiğinde en fazla mevsime 
uygun giyinme konusunda öğrencilerin bilgi edinmelerini sağlama $(\% 98,2)$; mevsime uygun yiyecek seçimi konusunda öğrencilerin bilgi edinmelerini sağlama $(\% 96,4)$; yerli malı ürünlerin tüketimine öncelik verme konusunda öğrencileri bilinçlendirmeye çalışma $(\% 93,6)$; doğal afetler ve doğal afetlerden korunma yollarına ilişkin bilgi edinmelerini sağlama $(\% 85,5)$ gibi uygulamaların gerçekleştirildiği görülmektedir. Buna karşın doğal afetlerden korunmaya ilgili STK yetkililerini kaynak kişi olarak davet etme $(19,1)$ ve öğrencilerin doğal ve beşeri unsurları sınıflandırmaları için geziler düzenleme $(\% 36,4)$ gibi uygulamaların en az gerçekleştirilen uygulamalar olduğu görülmektedir. Coğrafya okuryazarlığı ile ilgili sınıf öğretmenlerinin konularla ilgili bilgi edinme düzeyinde uygulamalar yaptığı buna karşın sınıf dışı geziler ve uzman kişileri sınıfa davet etme gibi uygulamaları düşük düzeyde gerçekleştirdikleri söylenebilir. Sınıf öğretmenlerinin, Sosyal Bilgiler dersinde öğrencilerine Politik Okuryazarlık becerisi kazandırmaya yönelik gerçekleştirdikleri uygulamalar Tablo 9'da verilmiştir.

Tablo 9

Sınıf öğretmenlerinin politik okuryazarlık bă̆lamında gerçekleştirdiği uygulamalar

\begin{tabular}{lll}
\hline Maddeler & f & \% \\
\hline Sınıf başkanı seçimlerini gerçek seçim havasıında gerçekleştirme & 104 & $\% 94,5$ \\
Sınıfta karar alma süreçlerine öğrencilerin etkin katılımı sağlama & 98 & $\% 89,1$ \\
Çocuk hakları konusunda öğrencilerin bilgi edinmelerini sağlama & 94 & $\% 85,5$ \\
Okul meclisi uygulamalarını ciddiyetle gerçekleştirme & 82 & $\% 74,5$ \\
Kamu kurum ve kuruluşlarını işleyişleri ile ilgili öğrencilerin bilgi edinmelerini sağlama & 66 & $\% 60$ \\
Öğrencilerin yerel yönetim birimleri hakkında bilgi edinmelerini sağlama & 65 & $\% 59,1$ \\
Aileleri, çocuklarını evde karar alma süreçlerine dâhil etmeleri konusunda bilgilendirme & 63 & $\% 57,3$ \\
Öğrencilerin çeşitli toplumsal sorunların çözümü için yardım kampanyası, kermes gibi & 30 & $\% 27,3$ \\
etkinlikler yapmalarını isteme & 13 & $\% 11,8$ \\
Çeşitli yerel yönetim birimlerine geziler düzenleme & 13 & $\% 11,8$ \\
Öğrencilerle birlikte çeşitli sivil toplum kuruluşlarının faaliyetlerine katılma & 11 & $\% 10$ \\
Çeşitli sivil toplum kuruluşları üyelerini sınıfa davet etme &
\end{tabular}

Tablo 9'da da görüldüğü gibi sınıf öğretmenlerinin politik okuryazarlık becerisini kazandırmaya yönelik en fazla sınıf başkanı seçimlerini gerçek seçim havasında gerçekleştirme $(\% 94,5)$; sınıfta karar alma süreçlerine öğrencilerin etkin katılımını sağlama 
$(\% 89,1)$ ve çocuk hakları konusunda öğrencilerin bilgi edinmelerini sağlama $(\% 85,5)$ gibi uygulamaları gerçekleştirdikleri görülmektedir. Buna karşın sınıfa çeşitli sivil toplum kuruluşları üyelerini davet etme (\%10); öğrencilerle birlikte çeşitli sivil toplum kuruluşlarının faaliyetlerine katılma $(\% 11,8)$ ve çeşitli yerel yönetim birimlerine gezi düzenleme $(\% 11,8)$ gibi uygulamaların en az gerçekleştirilen uygulamalar olduğu görülmektedir. Politik okuryazarlık ile ilgili bulgular incelendiğinde sınıf öğretmenlerinin bilgi edinmeye yönelik uygulamalara öncelik verdikleri buna karşın sınıf dışı uygulamalara yönelik etkinliklerin düşük düzeyde yer verildiği söylenebilir. Sınıf öğretmenlerinin, Sosyal Bilgiler dersinde öğrencilerine Hukuk Okuryazarlığı becerisi kazandırmaya yönelik gerçekleştirdikleri uygulamalar Tablo 10'da verilmiştir.

Tablo 10

Sınıf öğretmenlerinin hukuk okuryazarlığı bağlamında gerçekleştirdiği uygulamalar

\begin{tabular}{lll}
\hline Maddeler & f & \% \\
\hline Okul kurallarına uymaları konusunda öğrencileri teşvik etme & 106 & $\% 96,4$ \\
Tüketici hakları konusunda öğrencilerin bilgi edinmelerini sağlama & 104 & $\% 94,5$ \\
Toplumsal yaşamı düzenleyen kurallar konusunda öğrencilerin bilgi edinmelerini sağlama & 104 & $\% 94,5$ \\
Öğrencileri tüketici olarak haklarını kullanmalarını yönünde teşvik etme & 89 & $\% 80,9$ \\
Mesleki etik konusunda bilgi edinmelerini sağlama & 49 & $\% 44,5$ \\
Öğrencilerin ailelerini ve çevrelerindeki insanları trafik kurallarına uymaları konusunda & 33 & $\% 30$ \\
yönlendirmelerine yönelik çalışmalar yaptırma & \\
\hline
\end{tabular}

Tablo 10'da da görüldüğü gibi sınıf öğretmenlerinin Hukuk Okuryazarlığı becerilerini kazandırmaya yönelik en fazla okul kurallarına uymaları konusunda öğrencileri teşvik etme $(\% 96,4)$; tüketici hakları konusunda öğrencilerin bilgi edinmelerini sağlama $(\% 94,5)$; trafik kuralları gibi toplumsal yaşamı düzenleyen konularda öğrencilerin bilgi dinmelerini sağlama $(\% 94,5)$ gibi uygulamaların gerçekleştirildiği görülmektedir. Buna karşın gönüllü trafik polisi gibi uygulamalarla ailelerini ve çevrelerindeki insanları trafik kurallarına uymaları konusunda yönlendirmelerine yönelik çalışmalar yapma (\%30) ve mesleki etik konusunda öğrencilerin bilgi edinmesini sağlama $(\% 44,5)$ gibi uygulamaların en az yapılan uygulamalardan olduğu görülmektedir. Hukuk okuryazarlığı bağlamında sınıf öğretmenlerinin Sosyal Bilgiler dersinin 
kazanımlarıyla ilgili bilgi edinme düzeyinde uygulamaları gerçekleştirdiği buna karşın bu kazanımlar ile ilgili sınıf dışı uygulamalarına daha az gerçekleştirdikleri söylenebilir. Sınıf öğretmenlerinin, Sosyal Bilgiler dersinde öğrencilerine Eleştirel Okuryazarlık becerisi kazandırmaya yönelik gerçekleştirdikleri uygulamalar Tablo 11 'de verilmiştir.

Tablo 11

Sını öğretmenlerinin eleştirel okuryazarlık bağlamında gerçekleştirdiği uygulamalar

\begin{tabular}{lll}
\hline Maddeler & f & \% \\
\hline Derste fikirlerini belirtmeleri konusunda teşvik etme & 104 & $\% 94,5$ \\
Yapılan eleştirileri saygı ile karşılama konusunda teşvik etme & 99 & $\% 90$ \\
Sınıf başkanı seçimlerinde adaylarla ilgili görüşlerini belirtmeleri konusunda teşvik etme & 98 & $\% 89,1$ \\
Farklı durumlarla ilgili duygu ve düşüncelerini ifade etmeleri konusunda teşvik etme & 97 & $\% 88,2$ \\
Medya ile ilgili olumlu/ olumsuz fikirlerini söylemeleri konusunda teşvik etme & 75 & $\% 68,2$ \\
Farklı durumlara ilişkin çoklu bakış açısı geliştirmeye olanak tanıyacak uygulamalar yaptırma & 67 & $\% 60,9$
\end{tabular}

Tablo 11 incelendiğinde sınıf öğretmenlerinin Eleştirel Okuryazarlık becerilerini kazandırmaya yönelik en fazla öğrencileri derste fikirlerini belirtmeleri konusunda teşvik etme $(\% 94,5)$; öğrencileri yapılan eleştirileri saygı ile karşılamaları konunda teşvik etme (\%90); öğrencileri sınıf başkanı seçimlerinde adaylarla ilgili görüşlerini belirtmeleri konusunda teşvik etme $(\% 89,1)$ ve öğrencilerin farklı durumlarla ilgili duygu ve düşüncelerini ifade etmeleri konusunda teşvik etme $(\% 88,2)$ gibi uygulamaları gerçekleştirdikleri görülmektedir. Buna karşın öğrencilerin farklı durumlara ilişkin çoklu bakış açısı geliştirmelerine olanak tanıyacak uygulamalar düzenleme $(\% 60,9)$; öğrencilerin medya ile ilgili olumlu olumsuz fikirlerini söylemeleri konusunda teşvik etme $(\% 68,2)$ gibi uygulamaların en az gerçekleştirilen uygulamalar olduğu görülmektedir. Eleştirel okuryazarlık ile ilgili bulgular incelendiğinde sınıf öğretmenlerinin, öğrencileri kendi duygu ve düşüncelerini söyleme konusunda teşvik ettikleri buna karşın uygulamalara daha az yer verildiği söylenebilir. 


\section{Sonuç ve Tartışma}

Elde edilen bulgular 1şığında okuryazarlık becerilerinin kazandırılmasına yönelik sınıf öğretmenlerinin pek çok farklı uygulamaya yer verdiği söylenebilir. Araştırma sonucunda her bir okuryazarlık türüne ilişkin elde edilen sonuçlar şu şekilde özetlenebilir.

Ekonomi okuryazarlığılla ilgili bulgular incelendiğinde; sınıf öğretmenlerinin en fazla ders kitaplarında yer alan tutumluluk üzerinde durma, öğrencilerin doğal kaynakların etkili kullanımı ile ilgili bilgi düzeyinde kazanımlara yönelik uygulamaların yapıldığı görülmektedir. Buna karşın kurum, kuruluş ve fabrikalara götürme gibi sınıf dışında gerçekleştirilen uygulamaların sınıf öğretmenleri tarafından en az gerçekleştirilen uygulamalar olduğu görülmektedir. Akhan (2010) ilköğretim Sosyal Bilgiler öğrencilerinde ekonomi okuryazarlığının durumu ve geliştirilmesi üzerine gerçekleştirdiği araştırması sonucunda, ders kitabından geleneksel yöntemlerle de öğrencilerin ekonomi okuryazarlığ seviyesine ulaştıklarını ancak, bilgilerin günlük yaşamda kullanılmasının sağlanması ve bilgilerin daha kalıcı olmasının sağlanması konusunda uygulanan ekonomi programının etkililiğinin son derece açık olduğunu belirtmiştir. Bu araştırmada da sınıf içinde geleneksel öğretim yöntemleri ile gerçekleştirilen uygulamalara daha fazla yer verildiği, ekonomi programı kapsamında günlük yaşamla ilişkilendirmeye dayalı olarak tasarlanan etkinliklerin ise daha az uygulandığı belirlenmiştir. $\mathrm{Bu}$ bağlamda ekonomi okuryazarlığı becerisi kazandırmaya yönelik olarak sınıf öğretmenlerinin gerçekleştirdikleri uygulamaların ekonomi okuryazarlığg seviyesine öğrencileri ulaştırdığı, ancak öğrenilenlerin günlük yaşamda kullanılması noktasında yeterli uygulamaların yapılmadığı söylenebilir.

Çevre okuryazarlığı ile ilgili bulgular incelendiğinde sınıf öğretmenlerinin en fazla öğrencilerin yakın çevrelerindeki çevre sorunlarını belirlemelerini sağlama, öğrencilerin çevrecilik ile ilgili bilgi edinmelerini sağlama gibi kavram düzeyinde yapma gibi bilgiye dayalı etkinliklere öncelik verdiği; fidan dikme, gazete dergi gibi bilgilendirici çalışmaları 
Anadolu Journal of Educational Sciences International, July 2016, 6(2)

takip etme ve çevre kulübü gibi çalışmalara orta düzeyde yer verdiği; sivil toplum kuruluşlarıyla işbirliği yapma, uzman kişileri davet etme ve hayvan barınaklarına sınıf dışı gezi düzenleme gibi uygulamaların en az düzeyde yapıldığı görülmektedir. Artun ve diğerleri (2013)'deki araştırmalarında; doğa gezileri öğrencilerin çevre karşı duyarlılıklarını da artırdığı. Doğa gezilerinin bireyin çevre okuryazarı olmalarında etkili bir faktör olduğu sonucuna ulaşılmıştır. Karatekin (2012)'deki araştırmasında 4 ve 5. Sınıf Sosyal Bilgiler ders kitaplarında çevre okuryazarlık bağlamında; hakim içeriğin bilgi olduğu, beceri ve davranış boyutuna düşük düzeyde yer verildiği sonucuna ulaşı1mıştır.

Medya okuryazarlığı ile ilgili bulgular incelendiğinde sınıf öğretmenlerinin en fazla öğrencilerin farklı kaynaklardan araştırmalar yapmalarını sağlama $(\% 83,6)$; hava durumunu düzenli olarak takip etmelerini sağlama gibi araştırmaya yönelik uygulamalara yer verdiği. Buna karşın öğrencilerin medya analiz çalışmaları yapmalarını isteme $(\% 7,3)$; sınıfa karikatürler getirerek sınıf tartışmaları düzenleme gibi konuların karşılıklı tartışılabileceği en az gerçekleştirilen uygulamalar olduğu görülmektedir. Öğrencileri eleştirel düşünmeye yönlendirecek sınıf tartışmaların en az düzeyde gerçekleştirilmesi medya okuryazarı öğrenciler yetiştirme konusunda eksikliklere neden olabilir. Eleştirel düşünme ve medya okuryazarlığının birbiriyle ilişkili iki olgu olduğu ve bu olguların özellikle eğitimciler ve toplum için öneminin yadsınamaz olduğu açıktır (Karaman, 2016). Kurt ve Kürüm (2010)'da ki araştırmasında; medya okuryazarlığı bireylerden bir takım üst düzey düşünme becerilerini de beklemektedir. Bunlardan birisi de medya okuryazarlığı tanımı içinde de geçen olayların ve olguların açıklanmasında kanıtlara dayalı bakış açısının yapıcı biçimde ifade edilmesi olarak tanımlanabilen eleştirel düşünme becerisidir. Eleştirel bir medya okuryazarı birey medyanın dilini, sunulan mesajların farklı bağlamlarda üretildiğini, medyadan gelen bilgilerin doğruluğunun değerlendirilmesini ve süreçte yasal konulara dikkat edilmesi gerektiğini bilir. Aynı zamanda medyadaki mesajların çok büyük kitlelere hızlı biçimde yayıldığını ve kitleleri 
etkileyebildiğinin farkındadır. Bu durumda eleştirel bir medya okuryazarı medyayı bilinçli biçimde kullanır, medya karşısında aktif ve eleştirel bir yapı sergiler.

Tarih okuryazarlığı ile ilgili bulgular incelendiğinde: Evrensel ve ulusal değerler üzerinde durma, olayları kronolojik sıraya koyma gibi kavram boyutunda uygulamalara yer verildiği, buna karşın müzeye, sergiye ve tarihi binaları gösterme gibi sınıf dışı uygulamalara az yer verildiği görülmektedir. Ata ve Keçe (2014)' de öğrencilerin tarih okuryazarlığı düzeylerinin düşük olduğunu belirlemiş, bu durumun genel nedenlerinden bazılarını: Öğrencilerin Sosyal Bilgiler derslerine sınav odaklı yaklaşmaları, öğretmenlerin konu ve üniteleri programa uygun şekilde zamanında bitirme kaygısı, Sosyal Bilgiler programında kavram boyutunun daha ön planda olması nedeniyle beceri boyutunun ihmal edilmesi olarak ifade etmiştir. $\mathrm{Bu}$ araştırmada da sınıf öğretmenlerinin tarih okuryazarlığı bağlamında gerçekleştirdikleri uygulamaların programda yer alan kavram ve bilgilerin aktarılmasına yönelik olduğu, ilk elden bilgi edinme, gözlemleme, sınıf dışı mekânlardan yararlanma boyutunda uygulamalara nadiren yer verildiği belirlenmiştir. Araştırma sonuçları birbiri ile uyumludur.

Harita okuryazarlığı ile ilgili bulgular incelendiğinde yön bulma yöntemleri hakkında bilgi edinmelerini sağlama, yön bulmaya yönelik uygulamalı etkinlikler yapma, öğrencilerden kroki çizmelerini isteme gibi sınıf içi etkinliklere ağırlık verildiği görüldü. Buna karşın oryantiring uygulamaları yapma, Sosyal Bilgiler dersinde öğrencilerle birlikte yön bulmada kullanılabilecek "Google Haritalar” gibi uygulamaları az yaptıkları görülmektedir. Bu bağlamda sınıf dışı etkinliklere ve teknolojik imkanlardan faydalanma konularında öğretmenlerde eksiklikler görülmektedir. Tuna ve Balcı (2013)'de coğrafi becerilerin kullanıldığı oryantiring uygulamasında katılımcıların harita kullanma (sembolleri ve ölçekleri okuyabilme, uzaklıkları, yeryüzü şekillerini okuyabilme), haritada ve arazide yön bulma, konumunu belirleme, pusula kullanma, arazi çalışmalarını hazırlama, coğrafi bilgilerle pratik yapma, bilgileri değerlendirme, gerçek hayat problemleri ve çelişkili durumlarıyla mücadele 
etme gibi birçok becerisini artırdığını belirlemiştir. Oysaki bu araştırmada harita okuryazarlığı becerisinin kazandırılmasına yönelik olarak sınıf öğretmenlerinin en az belirttiği uygulamanın oryantiring olduğu görülmektedir. Harita okuryazarlığı becerisinin kazandırılmasında teorik uygulamalardan çok uygulamalı etkinliklere yer verilmesinin etkili ve verimli bir beceri kazandırma sürecine katkı sağlayacağı söylenebilir.

Teknoloji Okuryazarlığı becerisini kazandırmaya yönelik bulgular incelendiğinde en fazla derslerde teknolojik aletlerden yararlanma öğrencilerin çevresindeki teknolojik aletlerin kullanımı konusunda bilgilendirme yönünde uygulamalara yer verdikleri anlaşılmaktadır. Buna karşın öğrencilerin konu ile ilgili uzman kişilere e-posta aracılığ ulaşıp bilgi almalarına yönelik uygulamalar yapmalarını sağlama ve öğrencilerin power point gibi uygulamalarla sunum yapmalarını sağlama gibi beceriye dayalı uygulamalara en az gerçekleştirilen uygulamalar olduğu sonucuna ulaşılmıştır. ITEA'nın teknoloji okuryazarlığını, teknolojiyi kullanmak, yönetmek, değerlendirmek ve anlama yeteneği olarak tanımlamıştır (ITEA, 2006). $\mathrm{Bu}$ bağlamda teknoloji okuryazar öğrenciler yetiştirmek için anlama ve değerlendirmenin yanında öğrencilerin kullanma ve yönetme becerilerini de öncelik verilmesi gerektiği anlaşılmaktadır.

Coğrafya Okuryazarlığı ile ilgili bulgular incelendiğinde en fazla mevsime uygun giyinme konusunda öğrencilerin bilgi edinmelerini sağlama, mevsime uygun yiyecek seçimi konusunda öğrencilerin bilgi edinmelerini sağlama gibi uygulamaları gerçekleştirdiği görülmektedir. Buna karşın doğal afetlerden korunmaya yönelik AKUT, Sivil Savunma, AFAD gibi kurumlarla iletişime geçerek kaynak kişi davet etme ve öğrencilerin doğal ve beşeri unsurları sınıflandırmaları için geziler düzenleme gibi sınıf dışı uygulamalara en az yer verildiği görülmektedir. Taş ( 2008) ‘da coğrafi beceriler ve bunları öğrencilere kazandırma yolları ile ilgili araştırmasında Öğrencilerimize niteliksiz, her hangi bir beceri kazandırmayan, ezberci eğitim anlayışının önüne geçmek için, coğrafya öğretmenlerimiz, kendilerinin verilen 
Anadolu Journal of Educational Sciences International, July 2016, 6(2)

imkân ve firsatları en iyi şekilde kullanarak, coğrafyanın günlük hayatta nasıl kullanılabileceği ile ilgili coğrafi becerileri öğrencilerine kazandırmak zorundadırlar.

Politik Okuryazarlık ile ilgili bulgular incelendiğinde en fazla sınıf başkanı seçimlerini gerçek seçim havasında gerçekleştirme ve sınıfta karar alma süreçlerine öğrencilerin etkin katılımını sağlama gibi uygulamalara yer verildiği görülmektedir. Buna karşın sınıfa çeşitli sivil toplum kuruluşları üyelerini davet etme, öğrencilerle birlikte çeşitli sivil toplum kuruluşlarının faaliyetlerine katılma gibi uygulamaların en az gerçekleştirilen uygulamalar olduğu görülmektedir. Tarhan (2015) Sosyal Bilgiler öğretmeni adayları ile gerçekleştirdiği araştırmasında öğretmen adaylarının çoğunun kendini politik okuryazar olarak görmediği, çoğu kavramı içselleştiremedikleri sonucuna ulaşmıştır. Kavramların içselleştirilmesi için sivil toplum kuruluşları ile kurum ve kuruluşlar ile etkileşim içinde derslerin işlenmesinin bu sorunu ortadan kaldırabileceği söylenebilir. $\mathrm{Bu}$ araştırmadan elde edilen sonuçlar incelendiğinde ise sınıf öğretmenlerinin politik okuryazarlık becerisi kazandırmaya yönelik olarak sınıf dışı uygulamalara daha fazla yer vermesi gerektiği söylenebilir.

Hukuk Okuryazarlığı ile ilgili uygulamalar incelendiğinde sınıf öğretmenlerinin en fazla okul kurallarına uymaları konusunda öğrencileri teşvik etme ve tüketici hakları konusunda öğrencilerin bilgi edinmelerini sağlama gibi uygulamaların gerçekleştirildiği görülmektedir. Buna karşın gönüllü trafik polisi gibi uygulamalarla ailelerini ve çevrelerindeki insanları trafik kurallarına uymaları konusunda yönlendirmelerine yönelik çalışmalar yapma, mesleki etik konusunda öğrencilerin bilgi edinmesini sağlama gibi uygulamaların en az yapılan uygulamalardan olduğu görülmektedir. Oğuz (2013a)'de hukuk okuryazarı olma, hukuk kurallarını okuma-yazmanın ötesinde hukuk terimlerini doğru anlamaktır. Yaşamımızda bu terimlerle karşılaştığımızda doğru zamanda doğru yerde kullanabilme becerisine sahip olmalıdır. Hukuk devletleri var olduğu sürece toplum düzeni için hukuk kuralları var olacaktır. Önemli olan o kuralların var olması değil, o kuraların hayata geçirilebilmesidir. Bu 
Anadolu Journal of Educational Sciences International, July 2016, 6(2)

bağlamda araştırmanın sonucunda öğretmenlerin, öğrencileri hukuk okuryazarı yapma konusunda bilgi edinme çalışmalarının yanında bu hukuk kurallarını anlamlandırabileceği uygulamalara da yer vermesi gerekir.

Eleştirel Okuryazarlık ile ilgili bulgular incelendiğinde en fazla öğrencileri derste fikirlerini belirtmeleri konusunda teşvik etme ve öğrencileri yapılan eleştirileri saygı ile karşılamaları konunda teşvik etme gibi uygulamaları gerçekleştirdikleri görülmektedir. Buna karşın öğrencilerin farklı durumlara ilişkin çoklu bakış açısı geliştirmelerine olanak tanıyacak uygulamalar düzenleme ve öğrencilerin medya ile ilgili olumlu olumsuz fikirlerini söylemeleri konusunda teşvik etme gibi uygulamaların en az gerçekleştirilen uygulamalar olduğu görülmektedir. Özensoy (2011)'deki araştırmasında, eleştirel düşünmenin beceri temelli olarak öğretilmesinin diğer öğretim yöntemlerine göre anlamlı şekilde farklılık yarattı̆̆ı sonucuna ulaşmıştır.

Sosyal Bilgiler öğretimiyle çoklu okuryazar öğrenciler yetiştirebilmek için öncelikle öğretmenlerin çoklu okuryazar bireyler olması gerekir. Sınıf öğretmenlerinin okuryazarlık bağlamında Sosyal Bilgiler dersinde yer verdiği uygulamalar incelendiğinde öğrencilerin çoklu okuryazar birey olması bağlamında sınıf öğretmenlerinin, bilgi düzeyinde uygulamaları gerçekleştirdiği ancak öğrencinin günlük yaşamı ilişkilendirmesini sağlayacak beceri düzeyinde uygulamalara en az düzeyde yer verdiği sonucuna ulaşılmıştır. Bu bağlamda şu öneriler verilebilir:

- Okuryazarlık becerilerinin kazandırılmasında okul dışı öğrenme ortamlarından yararlanmaya yönelik hizmet öncesi eğitim ile öğretmen adaylarına; hizmet içi eğitim yoluyla da öğretmenlere destek sağlanabilir.

- Okuryazarlık becerilerinin kazandırılmasına yönelik öğrenciler üzerinde gerçekleştirilen uygulamaları içeren çeşitli deneysel araştırmalar yapılabilir. 
Anadolu Journal of Educational Sciences International, July 2016, 6(2)

- Sosyal Bilgiler dersinde çeşitli okuryazarlık becerilerinin kazandırılmasına yönelik uygulamalara yer veren kuramsal çalışmalar gerçekleştirilebilir.

\section{Kaynakça}

Aldemir, A. (2004). Öğretmen Adaylarının Bilgi Okuryazarlığı Düzeyleri Üzerinde Bir Araştırma: Sakarya Üniversitesi Örneği. Yayınlanmamış Yüksek Lisans Tezi. Hacettepe Üniversitesi/Sosyal Bilimler Enstitüsü, Ankara.

Akhan, N. E. (2010). İlköğretim Sosyal Bilgiler Öğrencilerinde Ekonomi Okuryazarlı̆̆ının Durumu ve Geliştirilmesi. (Yayımlanmamış Doktora Tezi) Gazi Üniversitesi / Eğitim Bilimleri Enstitüsü, Ankara.

Akhan, N. E. (2013). Ekonomi Okuryazarlığı. E. Gençtürk ve K. Karatekin (Ed.), Sosyal Bilgiler için Çoklu Okuryazarlıklar içinde (s. 78-109). Ankara: PegemA Yayıncılık.

Artun, H., Uzunöz, A. ve Akbaş, Y. (2013). Sosyal Bilgiler Öğretmen Adaylarının Çevre Okuryazarlık Düzeylerinin Değerlendirilmesi. Pamukkale Üniversitesi Eğitim Fakültesi Dergisi, 34 (2), 1-14.

Avsec, S., Jamsek, J. (2016). Technological literacy for students aged 6-18: a new method for holistic measuring of knowledge, capabilities, critical thinking and decision-making. Int J Technol Des Educ, 26, 43-60.

Barut, E., Demirer, V., Erbaş, Ç., Dikmen, C. H., Sak, N. (2016). Media literacy training for prospective teachers: instructional design process and its evaluation. Çukurova Üniversitesi Ĕ̆itim Fakültesi Dergisi, 45 (1), 49-70.

Büyüköztürk, Ş. (2011). Bilimsel Araştırma Yöntemleri. Ankara: PegemA Yayıncılık. 
Anadolu Journal of Educational Sciences International, July 2016, 6(2)

Cheung, C. K., Xu, W. (2016) Promoting media literacy education in China: a case study of a primary school. International Journal of Adolescence and Youth, 21(2), 215-217.

Clark, G. L. (2014). Roepke Lecture in Economic Geography: Financial Literacy in Context. Economic Geography, 90(1), 1-23.

Cooper, T. M. (2011). The legal literacy levels of educators in one family of schools in Ontario. Unpublished Master Thesis. Nipissing university schulich school of education North Bay, Ontario.

Deveci, H. ve Çengelci, T. (2008). Sosyal Bilgiler Öğretmen Adaylarından Medya Okuryazarlığına Bakış. Yüzüncü Yıl Üniversitesi Eğitim Fakültesi Dergisi, 5(2). 25-43.

Dikmenli, Y. (2015). Öğretmen Adaylarının Coğrafya Okuryazarlığı Algı Düzeylerinin Farklı Değişkenlere Göre İncelenmesi. Turkish Studies, 10(3), 353-368.

Duman, B.ve Girgin, M. (2007). Eğitim Fakültesi Öğrencilerinin Harita Okuryazarlığına İlişkin Görüşleri. Doğu Coğrafya Dergisi, 12 (17), 185-202.

Ekiz, D. (2003). Eğitimde araştırma yöntem ve metotlarına giriş. Ankara.

Guofeng, W., Gut, D. M. (2008). Media Use by Chinese and U.S. Secondary Students: Implications for Media Literacy Education. New Media and Education in the 21st Century, 47(3), 178-185.

Hayta, N. ve Akhan, N. E. (2014). İlköğretim Sosyal Bilgiler Derslerinde Ekonomi Okuryazarlığının Geliştirilmesi. Türkiye Sosyal Araştırmalar Dergisi, 18 (1), 205-230.

Hood, J., Stein, W., McCann, C. (2009). Low-cost insurance schemes in Scottish social housing: An empirical study of availability and tenants' participation. Urban Studies, 46, 1807-27. 
Anadolu Journal of Educational Sciences International, July 2016, 6(2)

İnan, S. (2014). Sosyal Bilgiler Eğitimi: Nedir, Ne Zaman ve Neden?. Öğretmenler ve ögretmen adayları için sosyal bilgiler eğitimine giriş içinde (1-21). Ankara: Anı Yayınc1l1k.

Kabapınar, Y. (2012). Kuramdan Uygulamaya Hayat Bilgisi ve Sosyal Bilgiler Öğretimi. Ankara: PegemA Yayınc1lık.

Karaman, M. K. (2016). Öğretmen Adaylarının Medya Okuryazarlık Düzeyleri ve Eleştirel Düşünme Eğilimleri Üzerine Bir Araştırma. Gümüşhane Üniversitesi İletişim Fakültesi Elektronik Dergisi, 4(1), 326-350.

Karasar, N. (2015). Bilimsel Araştırma Yöntemi. Ankara: Nobel Akademik Yayıncılık.

Karatekin, K. (2012). Environmental Literacy in Turkey Primary Schools Social Studies Textbooks. Procedia-Social and Behavioral Sciences, 46, 3519-3523.

Karatekin, K. ve Aksoy, B. (2012). Sosyal Bilgiler Öğretmen Adaylarının Çevre Okuryazarlık Düzeylerinin Çeşitli Değişkenler Açısından İncelenmesi. Turkish Studies, 7(1), 14231438.

Karatekin, K. (2013). Çevre Okuryazarlığı. E. Gençtürk ve K. Karatekin (Ed.), Sosyal Bilgiler için Çoklu Okuryazarlıklar içinde (s. 46-73). Ankara: PegemA Yayıncılık.

Kaminski, K., Seel, P., Cullen, K. (2003). Tecnology literate students: results from a survey. Educate Quarterly, 3, 35-40.

Kaya, H. (2014). Projelerin Coğrafya Öğretimi Açısından Önemi ve Coğrafya Öğretimine Katkıları. H. Kaya, A. Karatepe, A. Özder (Ed.), Modern Yöntem ve Teknikleri Coğrafya Öğretimi içinde (s. 1-13). Ankara: PegemA Yayıncılık. 
Anadolu Journal of Educational Sciences International, July 2016, 6(2)

Keçe, M. (2013). Sosyal Bilgiler Öğretiminde Yararlanılan Sınıf İçi Tarihi Roman Kullanım Tekniklerinin Öğrencilerin Tarih Okuryazarlığı Düzeylerine Etkisi. (Yayınlanmamış Doktora Tezi) Gazi Üniversitesi/ Eğitim Bilimleri Enstitüsü, Ankara.

Kurt, A. A. ve Kürüm, D. (2010). Medya Okuryazarlığı ve Eleştirel Düşünme Arasındaki İlişki: Kavramsal Bir Bakış. Mehmet Akif Ersoy Üniversitesi/ Sosyal Bilimler Enstitüsü Dergisi, 2(2), 20-34.

Lewin, S. J. (2016). Student as citizen: Teaching critical civic literacy skills in library. Knowledge Quest, 44(5), 29-31.

Livingstone, S. (2008) Engaging with media - a matter of literacy?. Communication, Culture \& Critique, 1 (1), 51-62.

Luckhardt, C. (2014). Teaching Historical Literacy and Making World History Relevant in the Online Discussion. Board Society for History Education, 47(2), 187-196.

International Technology Education Association. (2006). Technology For All: A Rationale and Structure for the Study of Technology. (https:/www.iteea.org) adresinden 30. 04. 2016 tarihinde erişilmiştir.

McBeth, W., Volk, T. L. (2010). The National Environmental Literacy Project: A Baseline Study of Middle Grade Students in the United States. The Journal Of Environmental Education, 41(1), 55-67.

MEB, Talim ve Terbiye Kurulu Başkanlığı (2004). Sosyal Bilgiler 4.-5. Sinıf Öğretim Programı. Ankara

Oğuz, S. (2013). Hukuk Okuryazarlığı. E. Gençtürk ve K. Karatekin (Ed.), Sosyal Bilgiler için Çoklu Okuryazarlıklar içinde (s. 160-176). Ankara: PegemA Yayıncılık. 
Anadolu Journal of Educational Sciences International, July 2016, 6(2)

Oğuz, S. (2013b). Ortaokul Öğrencilerinin Sosyal Bilgiler Eğitimi Çerçevesinde Hukuk Okuryazarlık Düzeylerinin Belirlenmesi. Yayınlanmamış Doktora Tezi. Gazi Üniversitesi/Eğitim Bilimleri Enstitüsü, Ankara.

Özensoy, A. U. (2011). Eleştirel Okumaya Göre Düzenlenmiş Sosyal Bilgiler Dersinin Eleştirel Düşünme Becerisine Etkisi. Mersin Üniversitesi Eğitim Fakültesi Dergisi, $7(2), 13-25$.

Öztürk, C. (2006). Sosyal Bilgiler: Toplumsal Yaşama Disiplinlerarası Bir Bakış. C. Öztürk (Ed.), Hayat Bilgisi ve Sosyal Bilgiler Öğretimi kitabı içinde (s. 21-50). Ankara: PegamA Yayıncilık.

Öztürk, F. Z. (2011). Sosyal Bilgiler Öğretmenlerinin ve Öğretmen Adaylarının İlköğretim Sosyal Bilgiler Dersi Programında Yer Alan Öğrenme Alanlarına İlişkin Özyeterlik Düzeylerinin İncelenmesi. Yayınlanmamış Doktora Tezi. Gazi Üniversitesi, Ankara.

Shihab, İ. A. (2011). Reading as Critical Thinking. Asian Social Science, 7(8), 209-218.

Sönmez, V. (2005). Hayat ve Sosyal Bilgiler Öğretimi ve Öğretmen Kılavuzu. Ankara: Anı Yayınc1lik.

Sönmez, Ö. F. (2013). Harita Okuryazarlığı. E. Gençtürk ve K. Karatekin (Ed.), Sosyal Bilgiler için Çoklu Okuryazarlıklar kitabı içinde (s. 138-156). Ankara: PegemA Yayınc1lik.

Stein, L., Prewett, A. (2009). Media Literacy Education in the Social Studies: Teacher Perceptions and Curricular Challenges. Teacher Education Quarterly, Winter, 131148. 
Anadolu Journal of Educational Sciences International, July 2016, 6(2)

Sümbüloğlu, V. ve Sümbüloğlu, K. (2000). Sağllk bilimlerinde araştırma yöntemleri. Ankara: Hatipoğlu Yayınları.

Tarhan, Ö. (2015). Sosyal Bilgiler Öğretmeni Adaylarının Politik Okuryazarlığına İlişkin Görüşleri. Akademik Sosyal Araştırmalar Dergisi, 3 (9), 649-669.

Taş, H. İ. (2008). Coğrafi Beceriler ve Bunları Öğrencilere Kazandırma Yolları. Doğu Coğrafya Dergisi, 20, 45-57.

Tuna, F. ve Balcı, A. (2013). Oryantiring Uygulamalarının Coğrafya Öğretmen Adaylarının Öz yeterlik Algılarına Etkisi. Marmara Coğrafya Dergisi, 27(1), 1-14.

Tuna, F. (2015). What is the Level of Undergraduate Students' Geographic Literacy in Turkey?. Hacettepe Üniversitesi Ĕ̆itim Fakültesi Dergisi, 30(2), 126-136.

Schwarz, G. (2001). Literacy Expanded: The Role of Media Literacy in Teacher Education. Teacher Education Quarterly, 28(2), 111-119.

Şimşek, H. ve Yıldırım, A. (2005). Sosyal Bilimlerde Nitel Araştırma Yöntemleri. Ankara: Seçkin Yayınevi.

Yiğit, E. Ö. (2011). Sosyal Bilgiler Öğretmen Adaylarının Teknoloji Okuryazarlı̆̆ı Düzeylerinin ve Teknoloji ile Bütünleştirilmiş Sosyal Bilgiler Öğretimine Yönelik Görüşlerinin Belirlenmesi. Yayınlanmamış Doktora Tezi. Marmara Üniversitesi/Eğitim Bilimleri Enstitüsü, İstanbul. 


\section{Extended Abstract}

Social Studies course mainly deals with people, society and the relationship between people and society. Therefore, it closely related to other disciplines including anthropology, archeology, economics, geography, history, law, philosophy, political science, psychology, religion and sociology as well as humanities, mathematics and natural sciences. In order to achieve the goals of Social Studies course individuals should be equipped with many varied skills and values. Some of these skills are related to literacy in the disciplines given above. The major literacy skills covered in Social Studies course include those about environment, law, economics, technology, history, media, maps, geography, critical approach and political. It is certain that in order to reinforce these skills first of all teachers should have these skills and must employ necessary teaching and learning activities related to these literacy skills in Social Studies courses. There are some studies dealing with literacy skills. However, the studies about Social Studies courses rarely deal with how each of these literacy skills can be reinforced and acquired through various teaching and learning activities and how these literacy skills can be gained through which types of teaching and learning activities. The aim of this study is to reveal which activities are used by classroom teachers to reinforce these literacy skills. In relation to this aim the study dealt with which activities were employed by classroom teachers to reinforce the literacy skills about environment, law, economics, technology, history, media, maps, geography, critical approach and politics. The participants of the study were a total of 110 classroom teachers working at nine different public primary schools in Afyon during the spring semester of the school year of 2015-2016. The schools where the participants were working at were selected from those serving for lower SES children (3), medium SES children (3) and higher SES children (3). The study was designed as a descriptive research. The data of the study were collected through a survey questionnaire developed by the authors. The data collection tool included 105 items about ten distinct 
literacy skills. The data were analysed using frequency and percentage. The findings of the study showed that the participants conducted activities about literacy skills, but they less dealt with those activities which related these activities with daily life practices. In addition, it was found that all activities concerning literacy skills done by the participants were consistent with the goals of Social Studies courses. Based on the findings of the study it can be suggested that in reinforcing literacy skills out of school environment should be used by teachers. This requirement can be emphasized both in teacher training programs and in inservice training courses. On the other hand, these activities should be analysed in future studies. 